\title{
ОЦЕНКА ВЛИЯНИЯ СОСТОЯНИЯ АРКТИЧЕСКОЙ ЗОНЫ РФ НА ИНВЕСТИЦИОННУЮ ПРИВЛЕКАТЕЛЬНОСТЬ *
}

\author{
(C) 2020 Кеворкова Ж. А.
}

доктор экономических наук, профессор Департамента аудита и корпоративной отчетности Финансовый университет при Правительстве Российской Федерации, Россия, Москва

E-mail: zhkevorkova@fa.ru

(c) 2020 Гизатуллина О.М.

кандидат экономических наук, доцент Департамента бизнес-аналитики Финансовый университет при Правительстве Российской Федерации, Россия, Москва

E-mail: OMGizatullina@fa.ru

В настоящее время инвестиционная привлекательность выступает в качестве обязательного условия конкурентоспособности субъектов Российской Федерации, ключевого фактора формирования их устойчивой экономики. Приток инвестиций в экономику того или иного региона способствует ускорению процессов модернизации производства, внедрению инновационных технологий, освоению производства новых видов продукции, оптимизации логистических затрат, а также повышению социальной и экологической эффективности, промышленного потенциала региона, благосостояния и качества жизни населения, а, следовательно, обеспечивает, в конечном итоге, устойчивое развитие региона. С другой стороны, рост экономики регионов, ускорение темпов роста регионального продукта способствуют достижению сбалансированности региональных бюджетов, обеспечивают стабильность налоговых поступлений в федеральный бюджет РФ.

Ключевые слова: анализ, оценка, инвестиции, инвестиционная привлекательность, факторы, Арктическая зона РФ.

В современных условиях повышение инвестиционной привлекательности субъектов Российской Федерации вообще и отдельных регионов, способных выступить в качестве точек роста всей российской экономики, в частности, является одной из приоритетных задач, решение которых осуществляется на высшем государственном уровне.

Некоторые результаты опубликованного рейтинга инвестиционной привлекательности субъектов Российской Федерации Национального рейтингового агентства по итогам 2019 г. представлены в таблице 1 [3].

Ключевые группы факторов, имеющие первостепенное значение для инвесторов при принятии решений о вложении средств в экономику того или иного региона представлены на рисунке 1.

Приоритетными задачами развития Арктической зоны, отмеченными в Стратегии развития АЗРФ и призванными стать триггерами инвестиционной привлекательности, являются освоение значительного ресурсно-сырьевого

потенциала региона и масштабные планы по созданию транспортно-логистических систем, способных обеспечить пространственную связанность Российской Федерации путем соединения крупнейших промышленных центров страны с портами северных морей.

Для оценки влияния состояния регионов АЗРФ на их инвестиционную привлекательность и возможности реализации транспортнологистических мегапроектов рассмотрим динамику основных показателей инвестиционной активности ключевых регионов за 2014-2018 гг. по данным Федеральной службы государственной статистики России, представленную в таблице 2 [2].

Таким образом, положительная динамика по объему инвестиций в основной капитал в 2018 г. зафиксирована только в четырех регионах, входящих в АЗРФ: Ямало-Ненецком и Чукотском $\mathrm{AO}$, Республике Саха (Якутия) и Мурманской области.

Согласно представленным в таблице 2 данным очевидным лидером в привлечении ин-

\footnotetext{
* Статья подготовлена по результатам исследований, выполненных за счет бюджетных средств по государственному заданию Финуниверситету
} 
Таблица 1. Результаты рейтинга инвестиционной привлекательности субъектов Российской Федерации Национального рейтингового агентства за 2019 г.

\begin{tabular}{|c|c|c|}
\hline Регион & Место в рейтинге 2019 г. & Изменение 2018-2019 гг. \\
\hline Москва & IC1 & Подтвержден \\
\hline Санкт-Петербург & IC2 & Понижен \\
\hline Ямало-Ненецкий АО & IC2 & Подтвержден \\
\hline Республика Татарстан & IC2 & Подтвержден \\
\hline Московская область & IC2 & Подтвержден \\
\hline Тюменская область & IC2 & Подтвержден \\
\hline Ленинградская область & IC2 & Подтвержден \\
\hline Сахалинская область & IC2 & Подтвержден \\
\hline Белгородская область & IC2 & Подтвержден \\
\hline Калининградская область & IC2 & Повышен \\
\hline \multicolumn{3}{|l|}{$\ldots$} \\
\hline Ненецкий АО & IC3 & Подтвержден \\
\hline \multicolumn{3}{|l|}{$\ldots$} \\
\hline Красноярский край & IC4 & Подтвержден \\
\hline Мурманская область & IC4 & Повышен \\
\hline \multicolumn{3}{|l|}{$\ldots$} \\
\hline Республика Саха (Якутия) & IC5 & Понижен \\
\hline \multicolumn{3}{|l|}{$\ldots$} \\
\hline Архангельская область & IC5 & Повышен \\
\hline \multicolumn{3}{|l|}{$\ldots$} \\
\hline Чукотский АО & IC5 & Понижен \\
\hline \multicolumn{3}{|l|}{$\ldots$} \\
\hline Республика Карелия & IC6 & Подтвержден \\
\hline \multicolumn{3}{|l|}{$\ldots$} \\
\hline Республика Коми & IC7 & Понижен \\
\hline
\end{tabular}

Источник: VII ежегодный рейтинг инвестиционной привлекательности регионов России 2019. Национальное рейтинговое агентство. URL: http://www.ra-national.ru/sites/default/files/Obzor_Rating_Investment_Regions_VII_2020.pdf Дата обращения: 20.02.2020.

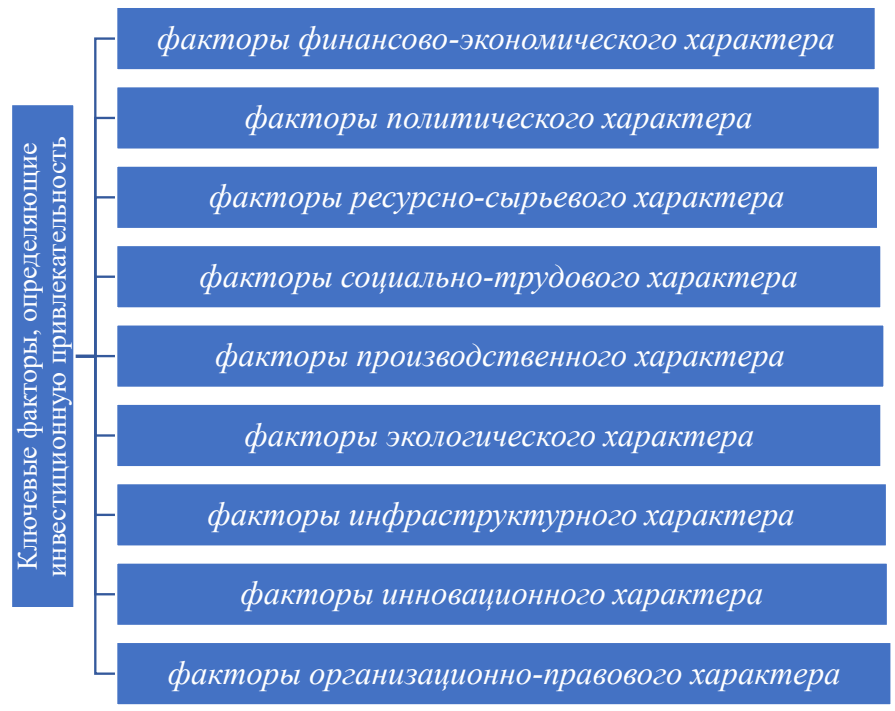

Рисунок 1. Ключевые факторы, определяющие инвестиционную привлекательность региона 
Таблица 2. Динамика инвестиций в основной капитал по регионам АЗРФ за 2014-2018 гт. (в фактически действовавших ценах, млн. руб.)

\begin{tabular}{|l|c|c|c|c|c|}
\hline \multicolumn{1}{|c|}{ Регион } & 2014 г. & 2015 г. & 2016 г. & 2017 г. & 2018 г. \\
\hline Ямало-Ненецкий АО & 754187 & 779406 & 1093082 & 1069620 & 1024427 \\
\hline Красноярский край & 363956 & 396865 & 425932 & 420886 & 420866 \\
\hline Республика Саха (Якутия) & 181172 & 198032 & 275576 & 386790 & 403427 \\
\hline Мурманская область & 85845 & 100418 & 85495 & 113269 & 144604 \\
\hline Республика Коми & 201032 & 169936 & 200261 & 134152 & 126595 \\
\hline Архангельская область & 78768 & 57718 & 83729 & 108915 & 100162 \\
\hline Ненецкий АО & 78952 & 114503 & 85703 & 106578 & 91156 \\
\hline Республика Карелия & 33400 & 32738 & 34700 & 41568 & 41237 \\
\hline Чукотский АО & 8386 & 14633 & 12757 & 12500 & 15068 \\
\hline
\end{tabular}

Источник: Регионы России. Социально-экономические показатели - Федеральная служба государственной статистики. Официальное издание. 2019. URL: https://www.gks.ru/storage/mediabank/Region_Pokaz_2019.pdf Дата обращения: 24.02.2020.

вестиций является Ямало-Ненецкий АО, что объясняется в первую очередь специализацией региона на добывающих секторах экономики. Порядка двух третей инвестиций в АЗРФ и более половины ВРП этих регионов приходится именно на Ямало-Ненецкий АО, в котором активно реализуются крупнейшие инвестиционные проекты, в том числе по добыче и транспортировке СПГ, развитию транспортно-логистических систем, что, в свою очередь, способствует снижению инвестиционных рисков региона.

Максимальное значение индекса физического объема инвестиций в основной капитал по регионам АЗРФ в 2018 г. зафиксировано в Мурманской области, где реализуется ряд крупных инфраструктурных проектов, направленных на развитие Северного морского пути.

Красноярский край также выступает одним из лидеров по объему инвестирования, в том числе по прямым иностранным инвестициям, что в первую очередь обуславливается высокой обеспеченностью региона природносырьевыми ресурсами. Основные направления инвестирования в регион: добыча нефти, угля, газа, руды и т.д.

Ненецкий АО выделяется полным отсутствием иностранных инвестиций в регион, начиная с 2016 г., что объясняется введением санкций на поставку в РФ технологий для добычи полезных ископаемых на арктическом шельфе. Отсутствие приемлемых альтернативных вариантов инвестирования определяет статус данного региона, наравне с Чукотским АO, как наименее инвестиционно-привлекательных регионов АЗРФ.

Республика Коми и Республика Саха (Якутия) являются лидерами по инвестированию в проекты, связанными с транспортировкой и хранением: порядка четверти инвестиций в основной капитал за 2018 г. в этих регионах были направлены именно в эти проекты [1].

Таким образом, повышение инвестиционной привлекательности регионов Арктической зоны Российской Федерации должно осуществляться в контексте их географических и природно-климатических особенностей, роли в реализации долгосрочной стратегии страны, уровня социально-культурного развития и демографических тенденций, развитости региональной инфраструктуры и достигнутого уровня хозяйственного развития и пр. Необходимо формирование комплексного подхода к оценке рисков, сопряженных с инвестиционной деятельностью в АЗРФ, разработка различных сценариев их реализации и мероприятий по минимизации возможных последствий.

\section{Библиографический список}

1. Орлов Д. Развитие Арктической зоны России и основные вызовы для ее освоения // Информационное агентство REGNUM. 25.04.2018. URL: https://regnum.ru/news/economy/2407690.html Дата обращения: 22.02.2020.

2. Регионы России. Социально-экономические показатели - Федеральная служба государственной статистики. Официальное издание. 2019. URL: https://www.gks.ru/storage/mediabank/Region_Pokaz_2019.pdf Дата обращения: 24.02.2020. 
3. VII ежегодный рейтинг инвестиционной привлекательности регионов России 2019. Национальное рейтинговое агентство.URL: http://www.ra-national.ru/sites/default/files/Obzor_Rating_Investment_Regions_VII_2020. pdf Дата обращения: 16.02.2020.

4. Кремин А.Е. Анализ методических подходов к оценке инвестиционной привлекательности территории региона // Вопросы территориального развития. 2019. Вып. 2 (47). С.1-11.

5. Петров А.М., Гизатуллина О.М., Мустафаева С.Р. Особенности и проблемы социально-экономического развития Арктической зоны Российской Федерации // Экономические науки. - 2020. - № 7 (188). - С.120127.

6. Шнайдер О.В., Петров А.М., Боровицкая М.В. Система оценки рисков, обусловленных влиянием суровых климатических условий на экономику Арктической зоны Российской Федерации // Экономические науки. 2019. № 171. С. 134-138. 